\title{
ЕФЕКТИВНІСТЬ МЕХАНІЗМУ ПРАВОВОГО ЗАХИСТУ КОНСТИТУЦЙНИХ ПРАВ І СВОБОД ЛЮДИНИ І ГРОМАДЯНИНА В УМОВАХ ПОЛТИКО-ПРАВОВИХ РЕФОРМ
}

\begin{abstract}
БЕДЬ Віктор Васильович - доктор богословських Наук, доктор юридичних наук, професор, ректор кафедри правознавства та канонічного права Карпатського університету імені Августина Волошина (м. Ужгород, Україна)

0000-0002-1817-8195

ПАЙДА Олексій Миколайович - доктор юридичних наук, професор, завідувач кафедри правознавства та канонічного права Карпатського університету імені Августина Волошина (м. Ужгород, Україна)
\end{abstract}

0000-0003-3541-9269

ЛАВРЕНТЬЕВ Юрій Германович - доктор юридичних наук, професор кафедри правознавства та канонічного права Карпатського університету імені Августина Волошина (м. Ужгород, Україна)

$0000-0003-4438-458 X$

DOI 10.32782/LAW.UA.2021.4.1

Політико-правові реформациї у світі потребують відповідних демократичних перетворень i в механізмі захисту прав та свобод громадян. Тому метою статті є визначення проблемних аспектів та способів їх подолання на шляху до забезпечення ефбективності механізму правового захисту конститущійних прав $i$ свобод людини $i$ громадянина в умовах політико-правових ре$\oint о р м$.

Для досягнення визначеної мети ми використали філособбсъкі, загальнонаукові та спеціально-наукові методи пізнання правових явищ, а саме: системний та герменевтичний підходи, діалектичний, бормально-логічний, статистичний, порівняльно-правовий методи.

y результаті проведеного дослідження ми опрацювали понятійно-категоріальний апарат "механізму захисту», базуючись на нормативно-правовій основі; проаналізували основні проблеми, що виниканоть у механізмі захисту прав та свобод громадян; дали характеристику суб'єктному складу механізму правового захисту; дали характеристику основним політико-правовим ребормам; визначили ризики, пов'язані із проведенням реборм та особливості правового захисту громадян, постраждалих внаслідок збройного конфлікту.
Отже, внаслідок проведеного дослідження ми встановили пряму залежність політикоправових реформ, що впливають на досягнення ефективності механізму захисту конституційних прав та свобод громадян, шо дало можливість зробити наступні висновки: $\varepsilon$ потреба у забезпеченні узгодженості державної політики та законодавства з міжнародними стандартами захисту прав та свобод; необхідно впроваджувати імплементацію міжнародного права у сбері захисту прав людини при проведенні політико-правових реборм з урахуванням ментальних та етнограббічних особливостей; забезпечення системності прийняття нормативних актів у сфері захисту прав та свобод сприятиме ефективності механізму; при проведенні реформ необхідний контроль за уникненням правових колізій між новим законодавством, пов'язаним iз проведенням реборм, та чинним, а також уникненням прогалин у праві; відповідність нормативних актів реальному стану суспільних відносин та збалансованість повноважень між суб'єктами є гарантією дієвості політико-правових реборм.

Ключові слова: права та свободи, механізм правового захисту, політико-правові ребборми, державна влада, громадянське сүспільство. 


\section{Теорія, історія держави і права, конституційне право}

\section{Постановка проблеми}

Розбудова України як «демократичної, правової, соціальної держави», закріплення в Конституції України положення про «найвищу соціальну цінність людини, її життя і здоров'я, честі і гідності, недоторканості і безпеки» вимагає формування нових підходів до захисту прав людини [1], особливо у період політико-правових реформ. Це положення має не лише нормативне підгрунтя, а й глибоко філософське, озвучене Кантом як підпорядкованість політики моралі і праву. Конституційна норма про «право будь-якими не забороненими законом засобами захищати свої права і свободи від порушень і протиправних посягань» [1, с. 55] надає «можливість здійснення громадянами певних вчинків щодо захисту власних прав і свобод і системи органів, які захищають і забезпечують ці права та свободи, утворюючи юридичний механізм захисту прав людини» [2].

У всій системі нормативного закріплення та правового регулювання механізму захисту конституційних прав і свобод людини і громадянина в умовах політикоправових реформ важливим аспектом залишається вміння держави гарантувати рівні можливості для всіх громадян скористатися цими способами захисту на власний вибір та виходячи із потреб, що і буде свідченням його ефективності. В іншому випадку все задеклароване у конституційних та законодавчих положеннях буде класифікуватися як фіктивне законодавство.

Ефективність механізму правового захисту забезпечується та зумовлюється багатьма чинниками й засобами, які у своїй сукупності переслідують спільну мету - зберегти та забезпечити найвищу соціальну цінність людини у всіх іiї правових статусах. Стан захищеності прав людини 6 iї природною потребою і з розвитком суспільних відносин, соціально-економічних перспектив та ризиків та, власне, в умовах політико-правових реформ потребують додаткового наукового та практичного дослідження та удосконалення. Ці питання наразі є предметом уваги у праві, політиці, науці тощо.
Аналіз аналіз останніх досліджень i публікацій

Н. Оніщенко зазначає, що «забезпечення належного захисту прав людини та громадянина в Україні є важливим завданням держави і актуальним напрямом розвитку правової системи. Для реалізації спрямування змін «на краще» у сфері прав людини влада повинна поставити їх у центр державної політики» [3].

Н. Опольська відзначає, що «саме категорія «механізм» дає змогу розглянути забезпечення прав та свобод людини як статичне явище, охарактеризувати його структуру, сукупність складових елементів, а також висвітлити особливості його функціонування, охарактеризувавши динамічні процеси, які виникають внаслідок функціонування цього механізму» [4].

3 часів незалежності України механізм забезпечення прав і свобод особи (до якого входить і захист як складовий елемент та процесуальна стадія) досліджували такі вчені, як: В. С. Журавський, О. В. Зайчук, А. П. Заєць, А. М. Колодій, М. П. Орзіх, Н. М. Оніщенко, А. Ю. Олійник, О. В. Петришин, О. Ф. Скакун, М. В. Цвік та інші. Здебільшого їх увага приділялась теоретико-правовим підходам до розуміння прав людини; забезпеченню прав та свобод громадян у контексті громадянського суспільства, проблемам реалізації прав та свобод, захисту прав та свобод у відповідних сферах державної діяльності, міжнародним стандартам прав людини тощо.

Оскільки сьогодні країна переживає реформаційні зміни у найважливіших сферах життя, включаючи й правову, постає гостра потреба зосередитись на підставах та ідейній основі, на яких відбуваються ці зміни, та яка їх мета. Існує нагальна потреба розуміння світоглядних, теоретичних та практичних основ захисту прав людини і громадянина, а тому науковий підхід у цьому питанні є вкрай необхідним.

Отже, можемо констатувати, що кількість наукових праць з проблематики прав людини є дійсно великою і дуже різноманітною. Це заслуговує на увагу, адже аспектів, пов'язаних із захистом прав людини в тому числі, дуже багато. Але, на жаль, часто на- 
укове дослідження проблем не є прямо пропорційним їх вирішенню на практиці.3 точки зору нормативного регулювання чинні міжнародні і національні механізми захисту прав людини $е$ абсолютно гуманними та необхідними. Та існує потреба у наближенні таких механізмів до реальних умов державного та суспільного життя, нових викликів в умовах політико-правових реформ та внутрішніх і зовнішніх глобальних ризиків і небезпек.

\section{Формування цілей статті}

Метою статті $є$ визначення проблемних аспектів та способів їх подолання на шляху до забезпечення ефективності механізму правового захисту конституційних прав i свобод людини і громадянина в умовах політико-правових реформ. Для досягнення мети дослідження ставимо наступні завдання: визначити основні проблеми та недоліки у забезпеченні прав та свобод громадян; дати правову оцінку дієвості нормативноправових актів у сфері захисту прав та свобод громадян в умовах внутрідержавних перетворень та зовнішніх загроз; проаналізувати взаємодію (та їі наслідки) при здійсненні політико-правових реформ 3 метою досягнення ефективності механізму захисту; дати характеристику системі заходів захисту прав та свобод громадян та їх особливостям у процесі реалізації органами влади, громадськими об'єднаннями та громадянами; визначити вплив світової глобалізації та російської окупації на механізм захисту конституційних прав та свобод у контексті міжнародних відносин; запропонувати основні організаційно-правові кроки України на шляху до забезпечення ефективності механізму правового захисту конституційних прав і свобод людини і громадянина в умовах політико-правових реформ.

\section{Результати дослідження}

Об’єтом дослідження є суспільні відносини, що виникають, змінюються і припиняються в результаті здійснення правового захисту прав та свобод громадян в умовах політико-правових реформ. Предметом дослідження - особливості забезпечення ефективності механізму правового захисту конституційних прав і свобод людини і громадянина в умовах політико-правових реформ.

Під час дослідження ми використали філософські, загальнонаукові та спеціальнонаукові методи пізнання правових явищ, а саме: системний, діалектичний, формальнологічний, статистичний, порівняльно-правовий методи; застосування герменевтичного підходу при роботі із національним та міжнародним законодавством дало можливість не тільки з'ясувати сенс правових норм, а й виявити тенденції демократичних перетворень в Україні на шляху до ефективності механізму правового захисту в умовах політико-правових реформ.

Системне реформування та демократичні перетворення, правові кроки України до входження в європейський та світовий правовий простір ставлять перед нею нові виклики до забезпечення ефективності механізму правового захисту, адже вся державно-владна діяльність має бути спрямована на подолання проблем захисту прав і свобод людини i громадянина, що виступатиме своєрідним показником на життєздатність політико-правових реформ та вірність обраного державою напрямку в контексті зміни якості суспільного життя.

Ми також не ідеалізуємо сучасну правову систему України та можемо відзначати прояви порушення правопорядку та законності; корупції та злочинності тощо. Свідченням того, що проблеми захисту прав та свобод громадян є наразі актуальними, є результати соціологічного опитування, проведеного у 2020 році Фондом «Демократичні ініціативи» імені Ілька Кучеріва у співпраці з Центром про права людини ZMINA за підтримки Програми розвитку ООН (ПРООН) в Україні: «ภише $20 \%$ опитаних успішно захищали свої права. Приблизно рівні частки респондентів (по 40\%) ніколи не намагалися захистити свої права або пробували їх захистити, але ці спроби були марними. Попри це, такі показники є значно кращими, ніж під час попередніх досліджень. Частка респондентів, які пробували захищати свої права, зросла з 42\% у 2016 році до 60\% - у 2020. I попри те, що основна частина респондентів не змогла захистити свої права у біль- 


\section{Теорія, історія держави і права, конституційне право}

шості випадків, збільшилась кількість тих, які успішно вирішили ці питання (з 14,5\% у 2016 році до 19,3\% у 2020-му). Тривожно те, що 22\% вважають, що в Україні взагалі немає способів захистити свої права. Найбільш ефективним способом захисту прав людини українці вважають звернення до засобів масової інформації (23\%). Звернення до суду - на другому місці (21\%). На третьому місці - звернення до Европейського суду з прав людини (20\%)» [5].

Світова глобалізація в цілому позитивно впливає на національну правову систему, акумулюючи зусилля органів державної влади стояти на варті захисту прав та свобод громадян $з$ метою інтегруватися до міжнародних об'єднань. У своєму прагненні Україна проводить ряд політико-правових реформ у напрямку конституціоналізму, законодавчої влади і демократії; організації виконавчої влади та державної служби; у сфері місцевого самоврядування та регіонального розвитку; адміністративних послуг та публічної адміністрації; організації та діяльності органів правопорядку; у сфері судочинства та запобігання корупції [6].

Чому виникає потреба розглядати механізм захисту прав та свобод громадян крізь призму політико-правових реформ?

- реформи сприяють якісному оновленню змісту законодавства з урахуванням потреб та інтересів громадян;

- правові реформи спрямовані на системні перетворення у правовідносинах між державою та суспільством;

- реформи проводяться з метою ліквідації негативних факторів, що впливають на рівень захищеності населення;

- правові реформи, власне, спрямовані на створення дієвого механізму забезпечення прав та свобод громадян 3 використанням національних та міжнародних інституційних та організаційних правових ресурсів.

Ми можемо розглядати механізм правового захисту як функцію безпосередньо держави в особі органів державної влади та місцевого самоврядування. I одночасно використовувати передбачені законодавством способи захисту, які стають можливими завдяки активній діяльності самих громадян:
«Кожен, чиї права та свободи було порушено, має право на ефективний засіб юридичного захисту в національному органі, навіть якщо таке порушення було вчинене особами, які здійснювали свої офіційні повноваження» [7] та «після використання всіх національних засобів юридичного захисту звертатися за захистом своїх прав і свобод до відповідних міжнародних судових установ чи до відповідних органів міжнародних організацій, членом або учасником яких $\epsilon$ Україна. Кожен має право будь-якими не забороненими законом засобами захищати свої права і свободи від порушень і протиправних посягань» [1, с. 55].

Аналіз наукових праць та чинного законодавства дав можливість вивести систему заходів, які становлять захист прав та свобод:

- попередження порушень прав громадян;

- контроль та нагляд за їх дотриманням;

- відновлення оскаржуваних чи порушених прав;

- накладання юридичної відповідальності на правопорушників;

- ліквідація негативних наслідків порушень прав громадян.

Варто відмітити, що не всі вчені розділяють таку сукупність заходів: деякі заперечують проти накладання юридичної відповідальності в межах процедури захисту, інші не відносять ліквідацію негативних наслідків тощо.

На нашу думку, якщо виходити із переліку суб'єктів, що мають право реалізувати ці заходи, а саме органи влади, громадські утворення та самі громадяни, то їх «комплексність» не викликає заперечень у контексті їх організаційних та правових можливостей приймати відповідні рішення та здійснювати процесуальні дії. Тим більше буде ефективність механізму правового захисту, чим активнішою буде взаємодія суб'єктів. Ми можемо вести мову як про взаємодію спільну, для досягнення єдиної мети; так і про взаємодію у контексті «стримувань та противаг» між суб'єктами.

На жаль, досить часто політики використовують популістські кроки, декларуючи ті 
чи інші матеріальні та нематеріальні блага (права і свободи) для своїх виборців, не реалізуючи їх у подальшому. Протидією у таких протизаконних діях є діяльність громадських організацій як у політичному, так і в інших сферах життєдіяльності суспільства. Тим більше їх діяльність активізується при реформаційних процесах у державі, адже громадські організації сприяють захисту конституційних прав та свобод громадян. I власне самі громадяни при порушенні їх прав та свобод мають можливість звернення до визначених законодавством інституцій за захистом.

Проблема порушення прав та свобод у межах провладних рішень може виникати не тільки на національному рівні, а й у формі міжнародної пропаганди, яку ми спостерігаємо у діях Російської Федерації відносно України. Країна-окупант маніпулює категорією «захисту прав людини», тим самим змушуючи Україну шукати шляхи для зменшення подібних проявів, що часто є складним як у процесуальному, так і в організаційному сенсі. Але якщо ми говоримо про відповідальність країни-агресора за порушення територіальної цілісності та незалежності суверенної держави, то поряд передбачаємо відповідальність правової держави за захист прав і свобод ії громадян.

У контексті ефективності механізму правового захисту конституційних прав і свобод кожної людини і громадянина наша держава постала перед викликами такого захисту окремих категорій громадян, які виникли у зв'язку з анексією АР Крим та окупацією Донбасу Російською Федерацією. Такі події слугували підставою прийняття низки нормативно-правових актів по забезпеченню прав і свобод внутрішньо переміщених осіб; громадян України, що залишились проживати на ТОТ та інших категорій, що постраждали внаслідок військових подій 2014 року, що продовжуються і досі. Зокрема, такими актами є закони України «Про забезпечення прав і свобод громадян та правовий режим на тимчасово окупованій території України» [8], «Про внутрішньо переміщених осіб» [9], «Про особливості державної політики із забезпечення державного суверенітету України на тимчасово окупованих територіях у
Донецькій та Ауганській областях» [10] та інші. Захист громадян України за будь-яких обставин є завданням України. I навіть тут ми не можемо відходити від конституційного принципу, що «забезпечення прав і свобод людини є головним обов'язком держави» $[1$, с. 3$]$.

Варто відзначити, що проводити будьякі реформи в умовах війни надто складно. У статті Романа Сона та Аріяни Гіць «Захід повинен діяти реалістично щодо України» автори зазначають, що необхідно виважено підходити до реформ з метою уникнення нестабільності та послаблення національної єдності. Ми погоджуємось із тим, що «Україна повинна бути новатором. А не копіювати не завжди найкращі західні практики» [11]. Тим більше при європеїзації реформ варто враховувати особливості правової системи, менталітету, фінансових та людських ресурсів, що можуть стати визначальними чинниками у їх результативності. Але ми не згодні, що «ресурсозатратні реформи слід відкласти». Адже це і є основною метою Росії - зупинити Україну в правовому розвитку, заморозити іiї зовнішні контакти.

По факту останніх подій важко передбачити, яким чином ті чи інші процеси створять загрозу правам та свободам та як впливатимуть на механізм їх захисту. Водночас, «вони не можуть бути скасовані, а при прийнятті нових законів або внесенні змін до чинних законів звуження змісту та обсягу дійсних прав і свобод не допускається» [1, ст. 22]. Отже, законодавець у зазначеній статті Конституції закладає гарантії захисту прав та свобод громадян при зміні правових положень в умовах політико-правових перетворень.

Верховна Рада України зробила заяву «про відступ України від окремих зобов'язань, визначених Міжнародним пактом про громадянські і політичні права та Конвенцією про захист прав людини і основоположних свобод» [12]. Такий вимушений крок здійснений Україною в межах нормативно закріпленого права на «відступ від договірних зобов'язань за надзвичайних обставин, у тому числі війни чи іншої суспільної небезпеки, що загрожує життю нації» [7], тому такий крок, на нашу думку, 


\section{Теорія, історія держави і права, конституційне право}

є абсолютно виправданим як з огляду фактичні, так і на нормативні підстави, і буде законним «до моменту виведення всіх незаконних збройних формувань, керованих, контрольованих і фінансованих Російською Федерацією, російських окупаційних військ, їх військової техніки 3 території України, відновлення повного контролю України за державним кордоном України, відновлення конституційного ладу та порядку на окупованій території України», про що зазначено у самій заяві.

Отже, «високе прагнення до загального благоденства», проголошене у Загальній декларації прав людини як «завдання, до виконання якого повинні прагнути всі народи і всі держави з тим, щоб кожна людина і кожний орган суспільства прагнули шляхом освіти сприяти поважанню цих прав і свобод і забезпеченню, шляхом національних і міжнародних прогресивних заходів, загального і ефективного визнання і здійснення їх як серед народів держав-членів Організації, так і серед народів територій, що перебувають під їх юрисдикцією» [13], на жаль, не є безумовним прагненням для всіх, кому адресовано.

Україна веде боротьбу як на внутрішньому, так і на зовнішньому фронті реформ. «Реалії XXI століття несуть конкретні ризики в контексті реалізації конституційних цінностей, особливо для країни у період системної нестабільності». Саме у такі моменти конституційні цінності мають стати дієвим інструментом захисту прав людини. Беззаперечно, важливою практикою 6 напрацьовані міжнародні стандарти та тенденції розвитку у сфері захисту прав людини, але «самі громадяни покладають на власні національні правові норми та гарантії, які відтворюють особливості національної правової системи в більш широкому аспекті» [14].

\section{Висновки}

3 наукової точки в контексті новизни результатів досліджуваної проблеми нами встановили пряму залежність політико-правових реформ на досягнення ефективності механізму захисту конституційних прав та свобод громадян як через нормативні підстави, внутрішньо-реформаційні процеси, вплив європейського курсу нашої держави та окупаційні дії Росії. Теоретико-прикладний характер дослідження призводить до наступних пропозицій, що сприятимуть досягненню поставленої мети. Оскільки реформи охоплюють практично всі сфери життєдіяльності суспільства, $з$ метою реалізації прав та свобод як громадянського, так і соціального, політичного, культурного характеру та досягнення ефективності механізму правового захисту конституційних прав і свобод людини і громадянина в умовах політико-правових реформ, необхідно забезпечити: узгодження державної політики та законодавства 3 міжнародними стандартами захисту прав та свобод; імплементацію міжнародного права у сфеpi захисту прав людини при проведенні політико-правових реформ 3 урахуванням ментальних та етнографічних особливостей; системність прийняття нормативних актів у сфері захисту прав та свобод людини i громадянина; уникнення правових колізій між новим законодавством, пов'язаним iз проведенням реформ, та чинним; уникнення прогалин при декларуванні реформи, але відсутності правового механізму їі реалізації в контексті виникаючих прав та свобод громадян; дотримання принципу «реальності» при прийнятті нормативних актів, тобто відповідності реальному стану суспільних відносин з можливістю їх реалізації; використання організаційних можливостей вчасного прийняття рішень у сфері захисту прав та свобод громадян, а не виявлення правової реакції постфактум, що викликатиме прояви правового нігілізму та свідчитиме про неефективність правового механізму; збалансованості повноважень між суб'єктами, що є гарантією дієвості політико-правових реформ.

Тобто можемо констатувати пряму залежність між захистом прав та свобод громадян та правовими реформами, адже саме останні є одним із найефективніших способів встановлення принципу верховенства права, законності та правопорядку, що 6 запорукою ефективності механізму правового захисту. Реалізація якісних правових реформ у кінцевому результаті має забезпечити основоположні ідеї соціальної цінності 
людини, її прав та свобод. Перспективи досліджень у поданому напрямку є достатньо широкими, адже є потреба у використанні наукового підходу, правових положень та прикладних аспектів, необхідних для подальшого вдосконалення ефективності механізму правового захисту в контексті динамічності реформаційних процесів з метою забезпечення найвищої загальнолюдської та суспільної цінності - прав та свобод громадян.

\section{Лiтература}

1. Конституція України: Закон від 28.06.1996 №254к/96-ВР. Верховна Рада України. URL: http//zacon2.rada.gov.ua.

2. Заварза С. А. Система захисту прав людини. Аозівсъка районна державна адміністрачія Харківської області: обіиійний

caŭm. URL: http://lozova-rda.kh.gov.ua/ news/299/59528 (дата звернення: 28 листопада 2021 року).

3. Оніщенко Н. М. Сучасний гендерний контекст: новели, перспективи, дискусії. Часопис Київського університету права. 2020. №3. С. 22-26. DOI: 10.36695/22195521.3 .2020 .01

4. Опольська Н. М. Механізм забезпечення прав та свобод людини у динамічному вимі. Підприємництво, господарство і право. 2019. № 4. С. 191-195. URL: http://socrates.vsau.org/repository/card. php?lang $=$ en\&id $=20464$ (дата звернення:28 листопада 2021 року).

5. Українці активніше захищають свої права: результати опитування. Профспілка працівників освіти $і$ науки Украйни: обічійний caüm. URL: https://pon.org.ua/novyny/8390ukrayinc-aktivnshe-zahischayut-svoyi-pravarezultati-opituvannya.html (дата звернення: 25 листопада 2021 року).

6. Законопроєкти у політико-правовій сфері, на які варто звернути увагу (станом на 25 жовтня 2021 року). Громадський простір. URL: https://www.prostir. $\mathrm{ua} /$ ?news = zakonoprojekty-u-polityko-pravovij-sferi-na-yaki-varto-zvernuty-uvahu-stanom-na-25-zhovtnya-2021-roku (дата звернення: 22 листопада 2021 року).

7. Про ратифікацію Конвенції про захист прав людини і основоположних свобод 1950 року, Першого протоколу та протоколів № 2,4,7 та 11 до Конвенції: Закон України від 17 липня 1997 року№ 475/97-BP. Верховна Рада Украӥни. URL: https://zakon.rada.gov.ua/laws/show/475/97$\%$ D0\%B2\%D1\%80?lang=uk\#Text

8. Про забезпечення прав і свобод громадян та правовий режим на тимчасово окупованій території України: Закон України від 15 квітня 2014 рокуo 1207-VII. Верховна Рада України. URL: https://zakon.rada.gov.ua/ laws/show/1207-18?lang=uk\#Text

9. Про забезпечення прав і свобод внутрішньо переміщених осіб: Закон України від 20 жовтня 2014 року № 1706-VII. Верховна Рада Украӥни. URL: https://zakon.rada.gov. ua/laws/show/1706-18\#Text

10. Про особливості державної політики із забезпечення державного суверенітету України на тимчасово окупованих територіях у Донецькій та Ауганській областях: Закон України від 18 січня 2018 року № 2268VIII. Верховна Рада Украӥни. URL: https:// zakon.rada.gov.ua/laws/show/2268-19\#Text

11. Sohn Roman, Gic Ariana. West needs to get real on Ukraine. Euobserver. 27 September 2017. URL: https://euobserver.com/opinion/139169 (дата звернення: 15 листопада 2021).

12. Про Заяву Верховної Ради України «Про відступ України від окремих зобов'язань, визначених Міжнародним пактом про громадянські і політичні права та Конвенцією про захист прав людини і основоположних свобод»: Постанова ВРУ від 21 липня 2015 р. №462-VIII. Верховна Рада Украӥни. URL: https://zakon.rada.gov.ua/laws/ show/462-19\#Text

13. Загальна декларація прав людини: ООН; Декларація, Міжнародний документ від 10.12.1948. Верховна Рада Украіни. URL: https://zakon.rada.gov.ua/laws/ show/995_015\#Text

14. Захист прав і свобод людини є найважливішим завданням держави - переконані учасники Міжнародного наукового семінару, що відбувся у КСУ (доповнено). Конституиійний Суд Украӥни: обічійний вебcaüm. URL: https://ccu.gov.ua/novyna/zahystprav-i-svobod-lyudyny-ye-nayvazhlyvishymz a v d a n n y a m - d e r z h av y - perek o n a n i uchasnyky-0 (дата звернення: 26 листопада 2021 року). 


\section{Теорія, історія держави і права, конституційне право}

\section{References}

1. Konstytutsiya Ukrayiny: Zakon vid 28.06.1996 №254k/96-VR. Verkhowna Rada Ukrainy. URL: http//zacon2.rada.gov.ua.

2. Zavarza S. A. Systema zakhystu prav liudyny. Lozivska raionna derzhavna administratsiia Kharkivskoi oblasti: ofitsiinyi sait. URL: http://lozova-rda.kh.gov.ua/ news/299/59528 (date of access: 28 November 2021).

3. Onishchenko Nataliia. (2020). Suchasnyi hendernyi kontekst: novely, perspektyvy, dyskusii [Contemporary gender context: novelties, perspectives, discussions]. Chasopys Kyivskoho universytetu prava [Scientific Journal «Chronicles of KUL], No. 3, 22-26. DOI: 10.36695/2219-5521.3.2020.01

4. Opolska N. M. (2019). Mekhanizm zabezpechennia prav ta svobod liudyny u dynamichnomu vymi. Pìdpriêmnictvo, gospodarstvo ì pravo, No. 4, 191-195. URL: http://socrates.vsau. org/repository/card.php?lang $=\mathrm{en \& id}=20464$ (date of access: 28 November 2021).

5. Ukraintsi aktyvnishe zakhyshchaiut svoi prava: rezultaty opytuvannia.[Ukrainians are more active in defending their rights: poll results. Profspilka pratsivnykiv osvity $i$ nauky Ukrainy: ofitsiinyi sait. URL: https://pon.org.ua/ novyny/8390-ukrayinc-aktivnshe-zahischayutsvoyi-prava-rezultati-opituvannya.html (date of access: 25 November 2021).

6. Zakonoproiekty u polityko-pravovii sferi, na yaki varto zvernuty uvahu (stanom na 25 zhovtnia 2021 roku) [Political and legal bills to pay attention to (as of October 25, 2021)]. (25.10.2021) Hromadskyi prostir. URL: https:// www.prostir.ua/?news=zakonoprojekty-u-polityko-pravovij-sferi-na-yaki-varto-zvernuty-uvahu-stanom-na-25-zhovtnya-2021-roku (date of access: 25 November 2021).

7. Pro ratyfikatsiiu Konventsii pro zakhyst prav liudyny i osnovopolozhnykh svobod 1950 roku, Pershoho protokolu ta protokoliv N 2, 4, 7 ta 11 do Konventsii: Law of Ukraine on July 17, 1997 № 475/97-BP. Verkhovna Rada of Ukraine. URL: https:// zakon.rada.gov.ua/laws/show/475/97 $\% \mathrm{D} 0 \% \mathrm{~B} 2 \% \mathrm{D} 1 \% 80$ ?lang=en\#Text

8. On Ensuring Civil Rights and Freedoms, and the Legal Regime on the Temporarily
Occupied Territory of Ukraine: Law of Ukraine on April 15, 2014 № 1207-VII. Verkhovna Rada of Ukraine. URL: https://zakon.rada.gov.ua/ laws/show/1207-18?lang =uk\#Text

9. Pro zabezpechennia prav i svobod vnutrishno peremishchenykh osib: Law of Ukraine on October 20, 2014 № 1706-VII. Verkhorna Rada of Ukraine. URL: https://zakon. rada.gov.ua/laws/show/1706-18\#Text

10. Pro osoblyvosti derzhavnoi polityky iz zabezpechennia derzhavnoho suverenitetu Ukrainy na tymchasovo okupovanykh terytoriiakh u Donetskii ta Luhanskii oblastiakh: Law of Ukraine on January 18, 2018 № 2268VIII. Verkhowna Rada of Ukraine. URL: https:// zakon.rada.gov.ua/laws/show/2268-19\#Text

11. Sohn Roman, \& Gic Ariana. (27 September 2017). West needs to get real on Ukraine. Euobserver. URL: https://euobserver.com/opinion/139169 (date of access: 15 November 2021).

12. Pro Zaiavu Verkhovnoi Rady Ukrainy «Pro vidstup Ukrainy vid okremykh zoboviazan, vyznachenykh Mizhnarodnym paktom pro hromadianski i politychni prava ta Konventsiieiu pro zakhyst prav liudyny i osnovopolozhnykh svobod»: Resolution of the Verkhovna Rada of Ukraine; Statement on May 21, 2015 № 462-VIII. Verkhovna Rada of Ukraine. URL: https://zakon.rada.gov.ua/laws/show/46219\#Text

13. Universal Declaration of Human Rights: UN; Declaration, International document on December 10, 1948. Verkhouna Rada of Ukraine. URL: https://zakon.rada.gov.ua/laws/ show/995 015\#Text

14. Zakhyst prav i svobod liudyny ye naivazhlyvishym zavdanniam derzhavy - perekonani uchasnyky Mizhnarodnoho naukovoho seminaru, shcho vidbuvsia u KSU (dopovneno) [Protection of human rights and freedoms is the most important task of the state - convinced the participants of the International Scientific Seminar held at the CCU (updated)]. Конститущійний Суд Украйни: обіиійний вебcaŭm. URL: https://ccu.gov.ua/novyna/zahystprav-i-svobod-lyudyny-ye-nayvazhlyvishym-zavdannyam-derzhavy-perekonani-uchasnyky-0 (date of access: 26 November 2021). 
Bed' Viktor

Doctor of Theology, Doctor of Law, Professor,

Rector Department of Law and Canon Law Augustyn Voloshin Carpathian University

Street Goydi, 4, Uzhhorod, aau_2006@ukr.net, $+38(067) 3108880$, 0000-0002-1817-8195

Paida Oleksii, Doctor of Law, Professor, Head of the Department of Law and Canon Law Augustyn Voloshin Carpathian University Street Goydi,4,Uzhhorod,pajda1@ukr.net, + 38 (050) 61138 24, 0000-0003-3541-9269

Lavrentiev Yurii, Doctor of Law, Professor of the Department of Law and Canon Law Augustyn Voloshin Carpathian University Street Goydi, 4, Uzhhorod,advocate.club.zk@gmail.com, +38 (050) $3178579,0000-0003-4438-458 X$

\section{EFFICIENCY OF THE MECHANISM OF LEGAL PROTECTION OF CONSTITUTIONAL RIGHTS AND FREEDOMS OF HUMAN AND CITIZEN}

Political and legal reforms in the world need appropriate democratic transformations in the mechanism of protection of the rights and freedoms of citizens. Therefore, the purpose of the article is to identify problematic aspects and ways to overcome them on the way to ensuring the effectiveness of the mechanism of legal protection of constitutional rights and freedoms of man and citizen in the context of political and legal reforms.

To achieve this goal we used philosophical, general scientific and special scientific methods of cognition of legal phenomena, namely: systemic and hermeneutic approaches, dialectical, formal-logical, statistical, comparative-legal methods.
As a result of the research, we worked out the conceptual and categorical apparatus of the "protection mechanism» based on the regulatory framework; analyzed the main problems arising in the mechanism of protection of rights and freedoms of citizens; gave a description of the subject composition of the mechanism of legal protection; gave a description of the main political and legal reforms; identified the risks associated with reforms and the specifics of legal protection of citizens affected by armed conflict.

Thus, as a result of our research we found a direct dependence of political and legal reforms that affect the effectiveness of the mechanism of protection of constitutional rights and freedoms of citizens, which allowed us to draw the following conclusions: there is a need to ensure consistency of state policy and legislation with international standards; it is necessary to implement the implementation of international law in the field of human rights protection in the implementation of political and legal reforms taking into account mental and ethnographic features; ensuring the systematic adoption of regulations in the field of protection of rights and freedoms will contribute to the effectiveness of the mechanism; when carrying out reforms, it is necessary to control the avoidance of legal conflicts between the new legislation related to the implementation of reforms and the current one, as well as the avoidance of gaps in the law; compliance of regulations with the real situation public relations and the balance of powers between the parties is a guarantee of the effectiveness of political and legal reforms.

Keywords: rights and freedoms, mechanism of legal protection, political and legal reforms, state power, civil society. 